\title{
Pengaruh Lamanya Pemberian Citicoline dalam Memperbaiki Retinal Nerve Fiber Layer (Rnfl) dan Lapang Pandangan pada Primary Open Angle Glaucoma (Poag)
}

Kemala Sayuti, Harmen, Hondrizal

\begin{abstract}
Abstrak
Tujuan penelitian ini adalah untuk menilai pengaruh lamanya pemberian citicoline dalam memperbaiki kualitas RNFL dan lapang pandangan pada POAG. Penelitian ini dilakukan pada pasien POAG yang datang dari bulan September 2010 - Januari 2011 dengan tehnik consecutive sampling. Semua subjek penelitian yang sudah diskrining dilakukan pemeriksaan OCT dan perimetri segera sebelum pemberian citicoline, pemeriksaan ulangan dilakukan setelah 10 hari pertama, 10 hari kedua, dan 10 hari ketiga pemberian citicoline. Dari penelitian ini didapatkan perbaikan ketebalan RNFL dengan pemeriksaan OCT lebih banyak terjadi pada pemberian citicoline selama 10 hari III (45.7\%) dibandingkan dengan pemberian 10 hari I (25,7\%) dan 10 hari II (42,9\%). Perbaikan mean sensitivity lapang pandangan dengan pemeriksaan perimetri lebih banyak terjadi pada pemberian citicoline selama 10 hari III $(51,4 \%)$ dibandingkan dengan pemberian 10 hari I (32.4\%) dan 10 hari II (37.2\%). Lama pemberian citicoline sangat berpengaruh meningkatkan ketebalan RNFL dengan pemeriksaan OCT dan mean sensitivity lapang pandangan dengan pemeriksaan perimetri pada pasien POAG dan bermakna secara statistik dengan $p=0.000$ dan $p=0.001$
\end{abstract}

Kata kunci: Primary Open Angle Glaucoma, Retinal Nerve Fiber Layer, Citicoline

\begin{abstract}
The objective of this study was to assessing the influence of duration of citicoline administration in improve the quality of RNFL and visual field in POAG. The study was conducted in patients with POAG who take place in September 2010 - January 2011 with consecutive sampling technique. After screening examination, subjects underwent OCT examination and early perimetry after the administration of citicoline, re-examination were in first 10 days, second 10 days, and third 10 days. RNFL thickness by OCT examination were much more going in citicoline administered for the third 10 days (45.7\%) compared with the provision of first 10 days (25.7\%) and second 10 day (42.9\%). Mean sensitivity improvements with visual field perimetry examination occurs more frequently in the administration of citicoline for the third 10 days (51.4\%), compared with 10 days of first administration (32.4\%) and second 10 days (37.2\%). Length of citicoline administration is influencing of RNFL thickness in OCT examination and improvement of the mean sensitivity of perimetry examination in patients with POAG and statistically significant, each with $p=0.000$ and $p=0.001$.
\end{abstract}

Keywords: Primary Open Angle Glaucoma, Retinal Nerve Fiber Layer, Citicoline

Affiliasi penulis : Bagian Mata, Fakultas Kedokteran Universitas Andalas

Korespondensi : Kemala Sayuti, email : kemala sayuti@yahoo.co.id Telp: : 0751-31746

\section{PENDAHULUAN}

Pada primary open-angle glaucoma (POAG) terjadi optik neuropati yang ditandai dengan kerusakan nervus optikus dan kehilangan lapang pandangan yang bersifat kronis dan slowly progressive. Peningkatan tekanan intra okuler (TIO) adalah faktor resiko yang sangat berperanan pada POAG disamping faktor lainnya seperti ras, umur, dan riwayat keluarga. Faktor lainnya yang berperanan adalah penurunan perfusi nervus optikus, kelainan metabolisme pada akson atau sel ganglion, dan kelainan matrik ekstra seluler lamina kribrosa, namun hingga sekarang beberapa dari faktor resiko ini belum bisa dijelaskan. Kehilangan lapang pandangan berhubungan dengan besarnya kerusakan nervus optikus. Pemeriksaan dengan menggunakan perimetri selama ini masih merupakan standar pengukuran secara klinis pada penderita glaukoma. Jika ditemukan hilangnya lapang pandangan tidak sesuai dengan kerusakan nervus optikus maka hal ini memerlukan pemeriksaan lebih lanjut.

Kemungkinan untuk terjadinya perbaikan fungsi visual masih diharapkan dan merupakan tujuan dari dokter mata dalam managemen glaukoma. Untuk mencapai hal itulah, Picori Giraldi dan kawan-kawan menganjurkan pemakaian citicoline pada pasien glaukoma, setelah melakukan penelitian mereka menemukan bahwa $75 \%$ pasien memperlihatkan gambaran perimetri yang lebih baik setelah terapi dengan menggunakan citicoline. .,3 $^{2}$

Cytidine-5-diphosphocholine (Citicoline atau CDP-choline) memberikan efek yang menguntungkan pada post trauma kepala dan penyakit neurodegenerasi. Citicoline bersifat neuroproteksi melalui peningkatan sintesis phosphatidylcholine (PtdCho). ${ }^{4}$ Neuroproteksi adalah topik penting yang pada awalnya mulai diteliti pada tahun 1970. Hal ini timbul berdasarkan konsep bahwa neuron yang mengelilingi daerah stroke iskemik sangat rentan untuk terjadinya degenerasi neuron sekunder. Pada tahun 1980 percobaan klinis dan eksperimen membuktikan kemungkinan intervensi farmakologi untuk melindungi jaringan otak akibat proses iskemia. Pada tahun 1990 
neuroproteksi telah mulai diaplikasikan pada perkembangan penelitian farmakologi untuk melindungi nervus optikus dari kerusakan dan memperbaiki kerusakan sel pada glaukoma. Selanjutnya berbagai penelitian dilakukan untuk perkembangan neuroproteksi pada glaukoma dan mengembangkan pengobatan terbaru pada glaukoma. ${ }^{5}$

Pada glaukoma, Retinal ganglion cell (RGC) mengalami apoptosis apabila terjadi gangguan hubungan dengan aksonnya atau bila akson terganggu hubungannya dengan target di intra kranial. Apoptosis RGC mulai terjadi dalam beberapa jam sampai beberapa hari dan terapi neuroproteksi berperanan mencegah terjadinya apoptosis pada kondisi seperti ini pada pasien glaukoma. ${ }^{8}$

Pada glaukoma, disamping terjadinya kematian sel, juga akan meningkatkan proses apoptosis yang akan menambah kematian RGC dan perburukan lapang pandangan. Apoptosis normal terjadi pada manusia, namun pada penderita glaukoma proses apoptosis lebih meningkat. Citicoline merupakan obat yang bekerja pada sel yang berfungsi dapat mencegah apoptosis, sehingga sel syaraf yang sekarat (dying cell) dapat diperbaiki dan berfungsi kembali sehingga dapat memperbaiki fungsi lapang pandangan. ${ }^{8}$

\section{Mekanisme Kerusakan Syaraf pada Glaukoma}

Walaupun penyebab yang tepat kematian RGC pada glaukoma belum sepenuhnya diketahui, namun beberapa mekanisme lain telah dikemukakan selain penekanan secara mekanis akibat peningkatan tekanan intra okular (TIO), faktor lain yang juga berperanan adalah apoptosis, neurotrophic factor deprivation, excitotoxicity, iskemia, hipoxia, dan stres oksidatif. ${ }^{1,6,16}$

Pemikiran lainnya adalah bahwa degenerasi RGC terjadi dalam 2 tingkat. Pertama, Karena kerusakan terjadi pada level akson syaraf optik yang memudahkan terjadinya kematian RGC. Kedua, karena keluarnya rangsangan yang merusak dari sel yang telah mati terhadap neuron disekitarnya yang menimbulkan kehilangan RGC secara progresif (degenerasi sekunder). ${ }^{35}$ Keduanya menyebabkan kematian yang progresif dari neuron yang sehat sehingga hal ini dapat menerangkan kenapa pasien glaukoma terus berlanjut kehilangan visualnya meskipun memberikan respon yang baik berupa turunnya TIO dengan terapi konvensional glaukoma yang sudah ada. $6,17,18$

\section{Induksi Apoptosis}

Apoptosis merupakan proses aktif, dimana sel mengalami banyak perubahan setiap waktu. Apoptosis merupakan proses alami dimana terjadinya kematian sel yang terus menerus. Proses ini di perantarai oleh caspases, yaitu protein yang dapat merusak sel tanpa menimbulkan inflamasi. Sel mengalami kemunduran dan kematian untuk kemudian difagositosis oleh makrofak yang mengelilinginya. Mitokondria merupakan kunci terjadinya proses apoptosis. Pada level tertentu apoptosis berhubungan dengan terjadinya homeostasis dan pergantian sel pada jaringan normal. Apoptosis yang berlebihan dan tidak terkontrol merupakan tanda terjadinya neurodegenerasi. ${ }^{3}$ Neuron yang mengalami apoptosis ditandai dengan perubahan morfologi dan berkurang atau menyusutnya sel, kromatin dan fragmentasi intra seluler. $^{6,7}$

Apoptosis terjadi pada banyak kelainan neurologi termasuk glaukoma. Proses apoptosis diketahui terjadi pada eksperimen terhadap binatang dan manusia yang menderita glaukoma. Studi yang dilakukan oleh Kerrigan dan kawan-kawan pada tahun 1997 memeriksa sejumlah spesimen penderita glaukoma dan pasien kontrol dengan menditeksi fragmentasi DNA yang menandai apoptosis. Pada eksperimen ini apoptosis ditemukan pada 10 dari 18 pasien glaukoma, dan hanya 1 dari 11 pasien kontrol. $^{17}$

Salah satu cara untuk mencegah terjadinya kematian sel syaraf adalah dengan menghambat proses apoptosis. Neurotropic factor yang dihasilkan oleh sel syaraf dapat menekan proses apoptosis dan bekerja secara langsung pada RGC, melindunginya dari berbagai faktor yang berperanan untuk timbulnya glaukoma diantaranya TIO tinggi, iskemia, inflamasi, dan faktor genetik. ${ }^{6,7,20}$

\section{Peranan Citicoline dalam Proses Apoptosis}

Citicoline (CDP-choline eksogen) tidak toksik dan ditoleransi dengan baik, dan digunakan pada terapi insufisiensi dan beberapa kelainan neurologi lainya seperti stroke, post trauma kepala dan penyakit Parkinson's. Sejumlah penelitian mengindikasikan bahwa citicoline dapat juga digunakan sebagai terapi pada pasien glaukoma. Glaukoma dianggap sebagai penyakit neurodegeneratif dimana terjadi kematian RGC secara perlahan karena proses apoptosis. CDPcholine endogen adalah prekursor alami seluler sintesis pospfolipid, terutama posfatidilcholine (PtdCho). Peningkatan sintesis Ptdcho dapat menghambat proses apoptosis dan memberikan efek neuroproteksi. Citicoline bila diberikan akan mengalami tranformasi menjadi cytidine dan choline yang diyakini masuk kedalam sel otak secara terpisah dan memberikan efek neuroproteksi dengan meningkatkan sintesis PtdCho. Efek yang sama juga diharapkan terjadi pada terjadi pada RGC glaukomatous. Selanjutnya citicoline merangsang sistem neurotransmiter otak, termasuk sistem dopaminergik. Dopamin diketahui sebagai neurotransmiter utama pada retina dan jalur visual post retina. Pada beberapa studi sebelumnya, terapi glaukoma disertai dengan citicoline menghasilkan perbaikan fungsi visual setelah diperiksa dengan metode eletrofisiologik. ${ }^{2,13}$

Pada penelitian ini akan menilai pengaruh lama pemberian citicoline dalam memperbaiki RNFL dan kualitas lapang pandangan pada POAG

\section{METODA PENELITIAN}

Desain penelitian berupa experimental prospective study dengan consecutive sampling. Populasi penelitian adalah semua pasien POAG yang memenuhi kriteria inklusi yang setuju diikutsertakan dalam penelitian serta menyanggupi untuk mematuhi aturan pemakaian obat oral dan jadwal kontrol yang ditentukan. Kriteria Eksklusinya yaitu kelainan media optik yaitu : opasitas kornea, katarak dan kekeruhan vitreus dengan visus $<5 / 60$, miopia tinggi $>6$ Dioptri,visus BCVA $<5 / 60$, degenerasi retina dan makulopati, penyakit infeksi mata yang masih aktif, kelainan anatomi dan fungsi kelopak mata, TIO tidak terkontrol dengan obat anti glaukoma topikal maupun sistemik. Pertama kali dilakukan pemeriksaan 
ketebalan RNFL dengan OCT dan lapang pandangan dengan perimetri sebelum dilakukan intervensi pemberian citicoline $1000 \mathrm{mg}$ oral, pemeriksaan selanjutnya pada hari 11,21 serta hari 31 setelah pemberian obat. Data diolah dengan menggunakan sistem komputerisasi, kemudian dilakukan analisa statistik memakai T.Test.

\section{HASIL PENELITIAN DAN PEMBAHASAN}

Tabel 1. Hasil Pemeriksaan OCT Berdasarkan

Pengelompokan $\begin{aligned} & \text { Ketebalan r RNFL } \\ & \text { Sebelum dan Setelah Pemberian } \\ & \text { Citicoline }\end{aligned}$

\begin{tabular}{|c|c|c|c|c|c|c|c|c|}
\hline \multirow{2}{*}{$\begin{array}{c}\text { Ketebalan } \\
\text { RNFL } \\
(\mu \mathrm{m})\end{array}$} & \multicolumn{2}{|c|}{$\begin{array}{c}\text { Pemeriksaa } \\
\mathrm{n} \text { awal }\end{array}$} & \multicolumn{2}{|c|}{$\begin{array}{c}\text { Pemeriksaa } \\
n \\
10 \text { hari I }\end{array}$} & \multicolumn{2}{|c|}{$\begin{array}{c}\text { Pemeriksaan } \\
10 \text { hari II }\end{array}$} & \multicolumn{2}{|c|}{$\begin{array}{c}\text { Pemeriksa } \\
n \\
10 \text { hari III }\end{array}$} \\
\hline & $\begin{array}{c}\mathrm{ma} \\
\text { ta }\end{array}$ & $\%$ & $\begin{array}{c}\mathrm{ma} \\
\text { ta }\end{array}$ & $\%$ & $\begin{array}{c}\mathrm{ma} \\
\text { ta }\end{array}$ & $\%$ & $\begin{array}{c}\mathrm{ma} \\
\mathrm{ta}\end{array}$ & $\%$ \\
\hline$>80$ & 12 & 34.3 & 13 & 37.2 & 12 & 34.3 & 12 & 34.3 \\
\hline $70-79$ & 3 & 8.6 & 6 & 17.1 & 8 & 22.9 & 9 & 25.7 \\
\hline $60-69$ & 6 & 17.1 & 4 & 11.4 & 3 & 8.6 & 2 & 5.7 \\
\hline $50-59$ & 5 & 14.3 & 5 & 14.3 & 4 & 11.4 & 5 & 14.3 \\
\hline $40-49$ & 6 & 17.1 & 5 & 14.3 & 7 & 20 & 6 & 17.1 \\
\hline$<40$ & 3 & 8.6 & 2 & 5.7 & 1 & 2.9 & 1 & 2.9 \\
\hline Jumlah & 35 & 100 & 35 & 100 & 35 & 100 & 35 & 100 \\
\hline
\end{tabular}

Dari tabel 1 setelah dilakukan beberapa pemeriksaan serial ditemukan bahwa, terdapat kenaikan yang signifikan ketebalan retina dari jumlah pasien kriteria early glaucoma pada pemeriksaan awal menjadi borderline glaucoma pada pemeriksaan 10 hari III, pada pemeriksaan awal pasien dengan early glaucoma sebanyak $17.1 \%$ menjadi $5.7 \%$ pada pemeriksaan 10 hari III, sedangkan borderline glaucoma sebanyak $8.6 \%$ menjadi $25.7 \%$ pada pemeriksaan 10 hari III. Lima mata dari pasien ini berasal dari early glucoma yang meningkat menjadi borderline glaucoma, hal ini memberikan gambaran bahwa pada glaukoma tahap awal kemungkinan untuk terjadinya perbaikan RNFL lebih tinggi dibandingkan dengan glaukoma pada tahap lanjut. Hal ini dapat terjadi kemungkinan karena pada glaukoma tahap lanjut sudah terjadi kematian sel lebih banyak sehingga sel tidak bisa diperbaiki, sedangkan pada glaukoma tahap awal terjadi kerusakan sel (dying cell) tapi belum menimbulkan kematian sel, sehingga sel masih bisa diperbaiki. Dari tabel terlihat bahwa pada pasien dengan glaukoma tahap lanjut mulai dari moderate hingga advanced thinning glaucoma hampir tidak terdapat perbaikan yang signifikan dari jumlah pasien setelah pemberian obat citicholine 30 hari.

Tabel 2. Pengaruh Lama Pemberian Citicoline Dibandingkan Pemeriksaan OCT Awal

kriteria

\begin{tabular}{lcccccc} 
& \multicolumn{2}{c}{$\mathbf{1 0}$ hari I } & \multicolumn{2}{c}{$\mathbf{1 0}$ hari II } & \multicolumn{2}{c}{$\mathbf{1 0}$ hari III } \\
menurun & 0 & $0 \%$ & 0 & $0 \%$ & 1 & $2.9 \%$ \\
menetap & 26 & $74.3 \%$ & 20 & $57.1 \%$ & 18 & $51.4 \%$ \\
membaik & 9 & $25.7 \%$ & 15 & $42.9 \%$ & 16 & $45.7 \%$ \\
Jumlah & $\mathbf{3 5}$ & $\mathbf{1 0 0} \%$ & $\mathbf{3 5}$ & $\mathbf{1 0 0} \%$ & $\mathbf{3 5}$ & $\mathbf{1 0 0 \%}$
\end{tabular}

Dari tabel 2 diatas terlihat bahwa terjadi perbaikan jumlah pasien dengan pemeriksaan OCT setelah 30 hari pemberian obat citicoline dimana terjadi peningkatan jumlah pasien yang membaik ketebalan RNFLnya yang sebelumnya $25.7 \%$ pada 10 hari I menjadi $42.9 \%$ pada 10 hari II dan $45.7 \%$ pada 10 hari III, dan juga terjadi penurunan persentase jumlah pasien yang menetap dari $74.3 \%$ menjadi $51.4 \%$. Hasil ini membuktikan bahwa semakin lama pemberian obat mengindikasikan terjadinya perbaikan sel syaraf pada retina yang tercermin dengan meningkatnya ketebalan retina pada pemeriksaan dengan OCT. Hasil ini sesuai dengan asumsi dari penelitian ini adalah bahwa dengan terjadinya perbaikan RNFL maka juga dapat meningkatkan fungsi retina untuk menghantarkan neuron sepanjang jalur visual yang secara objektif dapat diperiksa dengan berbagai alat. Hal sama juga didapatkan oleh Parisi dan kawan-kawan (2005) pada pasien glaukoma yang diberikan citicoline selama 2 bulan yang diikuti periode washout selama 4 bulan yang menemukan bahwa, terjadinya perbaikan fungsi retina yang secara objektif diperiksa dengan pattern eletroretinogram (PERG) dan meningkatnya hantaran neuron sepanjang jalur visual yang secara objektif diperiksa dengan visual evoked potential (VEP). ${ }^{11}$ Sumantri juga menemukan hal sama dengan penelitian selama 2 bulan terhadap pasien glaukoma dengan meningkatnya VEP, contras sensitivity dan berkurangnya mean defect dari perimetri. ${ }^{20}$ Penelitian ini menunjukkan ada perbedaan ketebalan atau terjadi peningkatan ketebalan RNFL setelah mendapatkan citicoline dibandingkan dengan sebelum mendapat citicoline dengan nilai $p=0.00$, yang artinya terjadi perbedaan yang bermakna secara statistik dari pemeriksaan awal dengan pemeriksaan 10 hari I, 10 hari II dan 10 hari III berikutnya. Jika dihubungkan dengan kriteria penilaian penelitian, maka peningkatan 
ketebalan RNFL dengan pemeriksaan OCT dikatakan membaik dibandingkan dengan periksaan awal terdapat setelah pemeriksaan 10 hari III. Hal ini menyimpulkan bahwa lama pemberian obat sangat berpengaruh terhadap perbaikan ketebalan RNFL. Parisi dan kawan-kawan(2005) menemukan bahwa pemberian obat yang lebih lama dan diulang secara periodik setelah pemberian pertama memberikan perbaikan yang lebih baik dibandingkan sebelumnya pada pemeriksaan dengan VEP dan PERG pada pasien glaukoma, karena selama ini diketahui bahwa gambaran yang abnormal dari VEP pada pasien glaukoma adalah akibat dari kerusakan hantaran neuron disepanjang jalur visual retina yang berhubungan dengan disfungsi lapisan retina (RNFL dan $\mathrm{RGC})^{3}$

\section{Hubungan Pemberian Citicoline dengan Lapang Pandangan pada Pemeriksaan Perimetri \\ Tabel 3. Hasil Pemeriksaan Perimetri Berdasarkan Pengelompokan Mean Sensitivity Sebelum dan Setelah Pemberian Citicoline}

\begin{tabular}{|c|c|c|c|c|c|c|c|c|}
\hline \multirow{2}{*}{$\begin{array}{c}\text { Mean } \\
\text { sensiti } \\
\text { vity } \\
\text { (db ) }\end{array}$} & \multicolumn{2}{|c|}{$\begin{array}{c}\text { Pemeriksaa } \\
\text { n awal }\end{array}$} & \multicolumn{2}{|c|}{$\begin{array}{c}\text { Pemeriksaa } \\
\text { n } \\
10 \text { hari I }\end{array}$} & \multicolumn{2}{|c|}{$\begin{array}{c}\text { Pemeriksa } \\
\text { an } \\
10 \text { hari II }\end{array}$} & \multicolumn{2}{|c|}{$\begin{array}{c}\text { Pemeriksaan } \\
10 \text { hari III }\end{array}$} \\
\hline & $\begin{array}{c}\text { mat } \\
\text { a }\end{array}$ & $\%$ & $\begin{array}{c}\text { mat } \\
\text { a }\end{array}$ & $\%$ & $\begin{array}{c}\mathrm{ma} \\
\text { ta }\end{array}$ & $\%$ & mata & $\%$ \\
\hline $10-15$ & 10 & 28.6 & 9 & 25.7 & 9 & 25.7 & 8 & 22.9 \\
\hline $16-20$ & 1 & 2.9 & 2 & 5.7 & 2 & 5.7 & 2 & 5.7 \\
\hline $21-25$ & 1 & 2.9 & 1 & 2.9 & 1 & 2.9 & 1 & 2.9 \\
\hline $26-30$ & 6 & 17.1 & 4 & 11.4 & 5 & 14.3 & 4 & 11.4 \\
\hline $31-35$ & 17 & 48.6 & 19 & 54.3 & 18 & 52.4 & 20 & 57.1 \\
\hline Jumlah & 35 & 100 & 35 & 100 & 35 & 100 & 35 & 100 \\
\hline
\end{tabular}

Pada tabel 3 diatas terjadi peningkatan mean sensitivity sedikit lebih tinggi dari $48.6 \%$ menjadi $57.1 \%$ pada kelompok mean sensitivity $31-35 \mathrm{db}$, dan berkurangnya jumlah pasien pada kelompok mean sensitivity 26-30, hal ini mengindikasikan bahwa terjadinya perbaikan sensitifitas retina pada kondisi dimana belum terlalu banyak skotoma yang terjadi pada perimetri atau mean sensitvity yang masih tinggi. Pada mean sensitivity yang rendah hampir tidak terdapat perbaikan sensitifitas karena kemungkinan sel syaraf yang mengalami kematian sangat banyak sehingga tidak terlalu banyak perbaikan. Penelitian oleh Pecori G (1989) juga menemukan hal sama, dimana setelah pemberian citicoline ditemukan berkurangnya daerah skotoma dan meningkatnya mean sensitivity pasien setelah mendapatkan terap citicoline. ${ }^{9}$ Penelitian yang dilakukan oleh Virno dan kawan-kawan (2000) pada pasien glaukoma yang diberi dengan citicoline secara periodik tiap 6 bulan selama 15 hari intra muskular dalam 10 tahun penelitian menemukan bahwa terjadi perbaikan yang signifikan sensitifitas retina yang diukur dengan perimetri pada tahun pertama dan meningkat secara stabil pada tahun berikutnya, sedangkan pasien glaukoma kontrol yang tidak diberikan citicoline memperlihatkan progresifitas penurunan sensitifitas retina setiap tahunnya.

\section{Tabel 4. Pengaruh Lama Pemberian Citicoline Dibandingkan Pemeriksaan Perimetri Awal}

\begin{tabular}{ccccccc}
\hline kriteria & \multicolumn{5}{c}{ Pemeriksaan perimetri } \\
\cline { 2 - 7 } menurun & 5 & $14.3 \%$ & 5 & $14.3 \%$ & 3 & $8.6 \%$ \\
menetap & 19 & $54.3 \%$ & 17 & $48.5 \%$ & 14 & $40.0 \%$ \\
membaik & 11 & $32.4 \%$ & 13 & $37.2 \%$ & 18 & 51.4 \\
Jumlah & $\mathbf{3 5}$ & $\mathbf{1 0 0 \%}$ & $\mathbf{3 5}$ & $\mathbf{1 0 0} \%$ & $\mathbf{3 5}$ & $\mathbf{1 0 0} \%$ \\
\hline
\end{tabular}

Pada tabel 4 diatas didapatkan bahwa terjadi perbaikan hasil pemeriksaan lapang pandangan dengan perimetri setelah 30 hari pemberian obat dimana dengan membaiknya lapang pandangan setelah makan obat pada 10 hari I sebanyak $32.4 \%$ menjadi $37.2 \%$ pada 10 hari II dan $51.4 \%$ pada 10 hari III. Namun hasil ini berbeda dengan penelitian yang dilakukan oleh Giraldi dan kawan-kawan (1989) menemukan bahwa dengan pemberian citicoline 1000 mg selama 10 hari didapatkan perbaikan lapang pandangan pada $75 \%$ pasien setelah pemeriksaan perimetri yang ditandai dengan berkurangnya daerah skotoma. ${ }^{9}$ Pada penelitian ini persentase hasil yang didapatkan tidak sama dengan yang didapatkan oleh Giraldi dan kawan-kawan dimana hanya didapatkan perbaikan lapang pandangan pada $32.4 \%$ pasien pada 10 hari I, kemungkinan hal ini akibat adanya faktor lain yang berpengaruh terhadap perbaikan lapang pandangan pada glaukoma selain tekanan intra okuler yang tidak bisa kita singkirkan, misalnya berat dan luasnya kerusakan lapang pandangan serta tingkat kerusakan pada RNFL, disamping itu tingkat konsentrasi dan perhatian pasien diperkirakan juga berpengaruh terhadap hasil pemeriksaan lapang pandangan. Hal yang sama juga ditemukan pada penelitian yang dilakukan oleh Rejdak dan kawankawan (2003) yang mendapatkan bahwa pemberian citicoline $1000 \mathrm{mg}$ oral mulai memperbaiki fungsi visual setelah pemberian selama 28 hari. $^{10}$

\section{KESIMPULAN DAN SARAN}

Lama pemberian citicoline sangat berpengaruh dengan meningkatnya ketebalan RNFL pada pasien POAG dengan pemeriksaan OCT dan bermakna secara statistik dengan $p=0.000$. Lama pemberian citicoline sangat berpengaruh dengan peningkatan mean sensitivity lapang pandangan pada pasien POAG dengan pemeriksaan perimetri dan bermakna secara statistik dengan $p=0.001$. Perbaikan ketebalan RNFL dengan pemeriksaan OCT lebih banyak terjadi pada pemberian citicoline selama 10 hari III $(45.7 \%)$ dibandingkan dengan pemberian 10 hari I $(25.7 \%)$ dan 10 hari II (42.9\%). Perbaikan mean sensitivity lapang pandangan dengan pemeriksaan perimetri lebih banyak terjadi pada pemberian citicoline selama 10 hari III $(51.4 \%)$, dibandingkan dengan pemberian 10 hari I (32.4\%) dan 10 hari II $(37.2 \%)$. Sebagai saran dalam penelitian ini adalah 
citicoline dapat dijadikan sebagai neuroproteksi pada pasien glaukoma tahap awal sebagai terapi tambahan selain terapi konvensional yang sudah ada. Pemeriksaan OCT dapat dijadikan sebagai penilaian secara invivo perbaikan RNFL setelah terapi dengan berbagai obat lainnya yang bersifat neuroproteksi. Untuk mengetahui berapa lama bertahannya efek terapi citicoline terhadap RNFL, maka mungkin diperlukan penelitian dengan berbagai kriteria penilaian dan pemberian obat yang lebih lama.

\section{DAFTAR PUSTAKA}

1. American Academy of Ophthalmology Introduction to Glaucoma : Terminology, Epidemiology, and Heredity. In : Glaucoma Section 10. 2008-2009; $p$ :3-15.

2. Parisi $V$ et al. Cytidine-5'-Diphosphocholine (Citicoline) Improve Retinal and Cortical Responses in Patients with Glaucoma in Ophthalmology. Vol. 106. Number 6. June 1999; p. 1126-1133.

3. Parisi V. Electrophysiological Assesment of Glaucomatous Visual Disfunction During Treatment with Cytidine-5'-Diphosphocholine (Citicoline): a Study of 8 Years of Follow-up in Documenta Ophthalmologica. 2005; 110: p.91-102.

4. Adibhatla RM, Hatcher JF, Demsey RJ. Citicoline:Neuroprotective Mechanisms in Cerebral Ischemia in Journal of Neuroschemistry. 2002; 80: p.12-23.

5. Shields MB. An Overview of Glaucoma. In Text Book of Glaucoma. 4th Ed. William \& Wilkins. 1998; $p: 1-2$

6. Weinreb RN. Glaucoma: Pathological and Clinical Feature in Neuroprotection for Glaucoma A Pocket Guide. Allergan. New York. 2007; p. 1-9.

7. Weinreb RN. Glaucoma Neuroprotection in The journal for the World Glaucoma Association. Desember. 2007.

8. Krupin T. Neuroprotection and Glaucoma in MedscapeCME Ophthalmology. 01/29/2010. diakses http:/cme.medscape.com/viewarticle 2008

9. Giraldi JP. et al. Therapeutic Value of Citicoline in the Treatment of Glaucoma ( Computerized and Automated Perimetric investigation) in International Ophthalmology. 1989; 13: p.109;112.
10. Rejdak R. et al. Oral Citicoline Treatment Improve Visual Pathway Function in Glaucoma in Med Sci Monit. 2003; 9(3): p. 124-128.

11. Parisi V. et al. Evidence of the Neuroprotective Role of Citicloline in Glaucoma Patient in Progress in Brain Research. Chapter 37. Vol 73. 2008; p. 541 . 554.

12. Rejdak R. et al. Neuroprotection in Glaucoma in research Group Neuroprotection dept. Pathology of Vision and Neuroophthalmology University Eye Hospital Tuebingen. diakses dari : www.uak.medizin.uni-tuebingen.de 2008

13. Grieb P, Rejdak R. Pharmacodinamics of Citicoline Relevant to the Treatment of Glaucoma in Journal of Neuroscience research. 2002; 67: p.143-148.

14. Cheung $W$ et al. Neuroprotection in Glaucoma in Optom Vis Sci. June. 2008; p.406-416

15. Hartwick AT. Beyond Intraocular Pressure: Neuroprotective Strategies for Future Glaucoma Therapy in Optometry and Vision Science. Vol. 78.No 2. 2001; p 85-94.

16. Dipolo A. Mechanism of Neural Injury in Glaucoma in Neuroprotection for Glaucoma A Pocket Guide. Allergan. New York. 2007; p. 18-30.

17. Crowston J. Biology of Neuronal Death in The journal for the World Glaucoma Association. Desember. 2007

18. Kaushick S, Pandav SS, Ram J. Neuroprotection in glaucoma. Journal of Postgraduate Medicine. Volume 49. 2003; p.90-95

19. Sumantri I. Clinical Evidence of the Neuroprotection Effect of RG-Choline in Glaucoma Treatment an Indonesian Study in the New Frontier in Glaucoma Study. Jakarta. October 2009.

20. Marrison CJ, Pallack PI. Anatomy Physiolog of the Optic Nerve. In Glaucoma Science and Practice. Thieme. New York. 2003; p.80-149

21. Virno $M$ et al. The Protective Effect of Citicoline on the Progression of the Perimetric Defect in Glaucomatous Patients (Perimetric Study with a 10-year follow-up) in Acta Ophthalmologica Scandinavica. Institute of Ophthalmology, Al Sapienza University. Rome. 2000. 